\title{
鋳型法によるナノカーボンの合成とその応用
}

\author{
京谷隆
}

東北大学多元物質科学研究所, 干 980-8577 仙台市青葉区片平 2-1-1.

\section{Synthesis of Nano-Carbons by the Template Method and their Applications}

\author{
Takashi Kyotani \\ Institute for Multidisciplinary Research for Advanced Materials, Tohoku University, 2-1-1 Katahira, Aoba-ku, Sendai 980-8577.
}

Received May 12, 2004

\begin{abstract}
SYNOPSIS
Using uniform nano-channels of aluminum anodic oxide film as a template, uniform and unique multiwalled carbon nanotubes can be synthesized with a selectivity of $100 \%$. This technique allows one to precisely control the diameters and the length of nanotubes. Moreover, this method makes them possible to chemically-modify only the inner surface of carbon nanotubes and to prepare carbon nanotubes with double coaxial structure of heteroatomdoped multiwalls. Metal or metal oxide filled nanotubes can also be synthesized by this method and highly-crystallized inorganic nano-rods or nano-ribbons cab be fabricated using the cavity of the carbon-coated nano-channels as a reaction field. In addition to one dimensional nano-carbons like carbon nanotubes, unique nano-porous carbon can be prepared by the template technique. Micro and mesoporous carbons with surprisingly regular ordering can be synthesized using zeolite and mesoporous silica templates, respectively. In this review, we introduce such templatemediated approach and highlight how useful and versatile the template technique is for the production of nanocarbons.
\end{abstract}

KEYWORDS

template technique, carbon nanotube, metal nano rod, microporous carbon, mesoporous carbon

\section{1 緒 言}

ダイヤモンドなどを除いて，カーボンの構造は基本的には 多環芳香族分子の集合体であると考えてよく，分子の形やそ の集合様式の違いによって，カーボンの鷩くべき多様性が生 まれる。したがって，このような巨大分子の形や集合状態を ナノレベルで制御することができれば，ユニークな構造をも ち今までにない高い性能を示すナノカーボン材料を作り出す ことが可能となる．本稿ではそのような精密制御法の1つと して「鋳型法」を紹介する。

鋳型炭素化法は，無機物の制御された空間内で有機物の炭 素化を行った後，鋳型である無機物を除去することでカーボ ンを得る方法である。この方法では使用する鋳型の種類や構 造を変化させることによりカーボン構造のナノレベルでの制 御が可能となり，通常の方法では得られないユニークな構造 のナノカーボンをつくることができる.ここでは, 1 次元鋳型 を用いたカーボンナノチューブの合成と,3次元鋳型よる多孔
質カーボンの合成について述べる。

21 次元鋳型を用いたカーボンナノチュープの合成 カーボンナノチューブの製造法としては, アーク放電法, レーザ一蒸発法, 炭化水素触媒分解法などが知られているが, どの手法においてもチューブ径や長さなどを自在に制御する ことは簡単ではない。しかし，もしサイスをを自在に制御しう る 1 次元ナノチャンネルを鋳型としてカーボンナノチューフ を合成することができれば，鋳型のサイスを変えることでナ ノチューブの径や長さの精密制御も可能となる.このような 1次元状のナノチャンネルをもつ物質の1つとしてアルミニウ ム陽極酸化皮膜がある. 陽極酸化皮膜には膜面に垂直で均一 なナノメータースケールの直線状細孔が多数貫通しており， 陽極酸化時の電解条件を変化させることで細孔径,細孔密度, 細孔の長さを容易に制御することができる.アルミニウム陽 極酸化皮膜の細孔を鋳型とすることで，高分子，金属あるい 
㹥金属化合物のナノチューブやナノワイヤなど数多くの 1 次 元状ナノ物質が作られているが, 炭化水素ガスの化学気相析 出(CVD)によりカーボンナノチューブの合成も可能となる. この鋳型を用いたナノチューブの合成法はサイスの精密制御 だけでなく, 他の方法には真似の出来ない実に様々な構造制 御を可能にする.

2.1 鋳型法によるカーボンナノチューブの合成 1,22

アルミニウム陽極酸化皮膜を鋳型としたカーボンナノ チューブの合成方法は以下の通りである. まず，陽極酸化皮 膜を反応管に入れ, $800^{\circ} \mathrm{C}$ 程度の温度でプロピレン $\left(\mathrm{C}_{3} \mathrm{H}_{6}\right)$ な どの炭化水素ガスを流す.一般に炭化水素ガスは高温になる と気相中で分解し, 熱分解カーボンとして陽極酸化皮膜の外 表面および細孔内壁に堆積する. 陽極酸化皮膜の表面は炭素 堆積に対して強い触媒作用があり,このため鋳型細孔内のナ ノ空間においても細孔内壁への均一なカーボン堆積が可能と なる.このようにして生成したカーボン被覆陽極酸化皮膜を フッ酸あるいは濃厚アルカリ溶液で処理する. 陽極酸化皮膜 は無定形のアルミナ(酸化アルミニウム)なのでフッ酸あるい はアルカリ処理で容易に溶解し, 堆積したカーボンが不溶分 として残る. Fig.1にこの実験スキームの概略を示す.この戉 から, カーボンが直線状細孔の内壁に均一に堆積すれば, 束 状のナノチューブが処理後の不溶分として取り出せることが わかるだろう. また, この方法では金属触媒が必要で無いこ とも大きな特徵である.

Fig. 2 に細孔径 $30 \mathrm{~nm}$ と $230 \mathrm{~nm}$ の陽極酸化皮膜から調製した カーボンの走查型電子顕微鏡 (SEM) 写真を示す. どちらの場 合も均一なチューブ状のカーボンのみが観察され, その外径 は鋳型として使用した陽極酸化皮膜の細孔径にほぼ等しい。 また, Fig.1 (a) と (c) では長さ $70 \mu \mathrm{m}$ 程度の束状になったカー ボンチューブが認められ, この長さは使用した陽極酸化皮膜 の厚さに等しい. 陽極酸化皮膜の外表面にもカーボンが唯積 したため, チューフ同士がその端部でつながっている. Fig.2 (b) と(d)のようにチューブが1つ1つ独立で観察できたのは, フッ酸処理の摚汼中に束状のものからチューブが 1 本 1 本取 れていったためと考えられる.

以上から，本法により選択的にカーボンチューブのみを合 成することができ，しかもチューブの径と長さはそれぞれ鋳

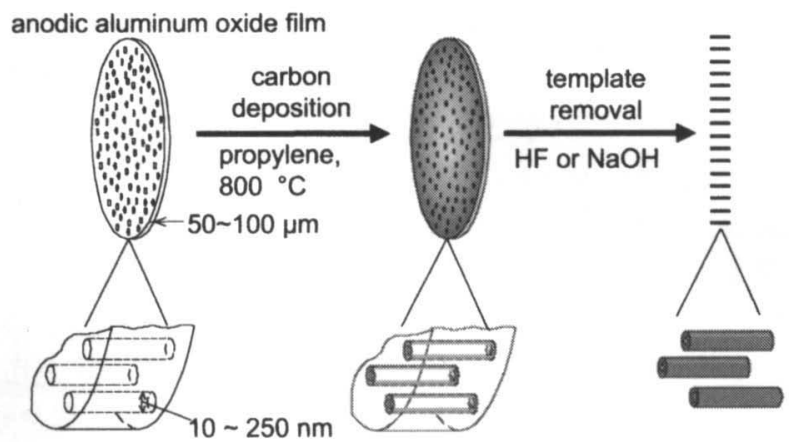

Fig.1 Synthesis processes of the carbon nanotubes using aluminum anodic oxide film as a template.
型となる陽極酸化皮膜の細孔径と厚さを変化させることで制 御できることが明らかとなった.

2.2 カーボンナノチューブの化学修飾と透過膜としての利用

カーボンナノチューブの表面にホウ素, 窒素, 酸素などの ヘテロ原子を導入することで, 性能の向上のみならず新機能 の発現も期待できる. そのため, ナノチューブの化学修飾に 関する研究が盛んに行われている. 鋳型法により合成したナ ノチューブも化学修飾することは容易であり，しかも鋳型法 ならではの細かい芸当ができる. 鋳型法からのナノチューブ の特徵の一つは両端が開いた構造をしていることである.し たがって, 反応物質をチューブ内部に導入するのは閉口構造 のアーク放電法からのものに比ぺてきわめて容易である. ま た, 鋳型を除去する前の複合体の段階で化学修飾の処理を行 えば,チューブの内部だけを選択的に改質することができる. たとえば，以下のような方法で簡単にナノチューブの内面だ けに酸素原子を導入することができる ${ }^{3)}$.

まず,アルミニウム陽極酸化皮膜上でプロピレンCVD (800 $\left.{ }^{\circ} \mathrm{C}\right)$ を行い, 炭素被覆陽極酸化皮膜複合体を調製する．この複 合体を $20 \mathrm{wt} \%$ 硝酸中で 6 時間環流処理をして, 複合体の細孔 内表面に含酸素官能基を導入する. その後, 複合体から鋳型 であるアルミナをアルカリ処理により溶解除去して, カーボ

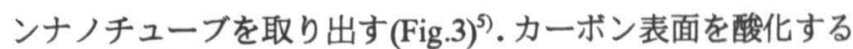
方法はいくつかあるが, 硝酸処理はその中でも最も強力な方 法の 1 つで, とくにカルボキシル基を導入するのに効果的で ある. Fig.3からわかるように, 複合体の段階で処理を行うの で, 複合体の外表面と細孔の内壁, つまりナノチューブの内 表面が酸化される.しかし, チューブの外側は鋳型のアルミ ナで覆われているので, 酸化されない.つまり,この方法を 利用することでチューブ内表面だけを選択的に酸化でき，外 表面は疎水性を保っているが内表面はそれより親水性が高い 特殊な表面特性をもつナノチューブが合成できる.

酸化処理だけでなく, 内表面のフッ素化も行える. フッ素
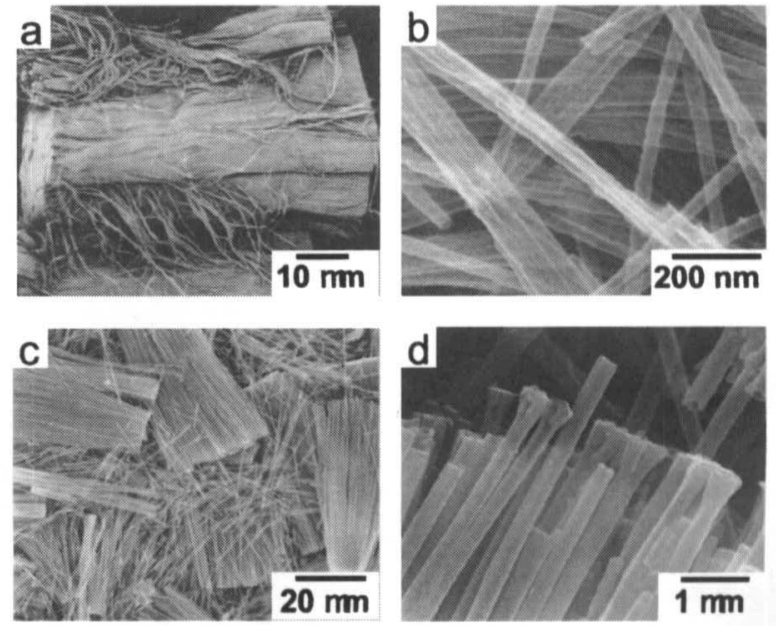

Fig.2 SEM photographs of the carbon nanotubes prepared using aluminum anodic oxide film with a channel diameter of $30 \mathrm{~nm}$ (a, b) and $230 \mathrm{~nm}(\mathrm{c}, \mathrm{d})$. 


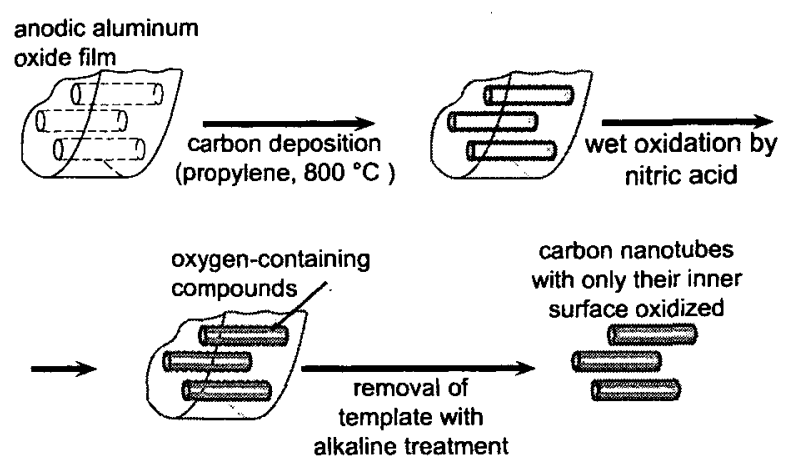

Fig.3 Selective oxidation of the inner wall of the carbon nanotubes.

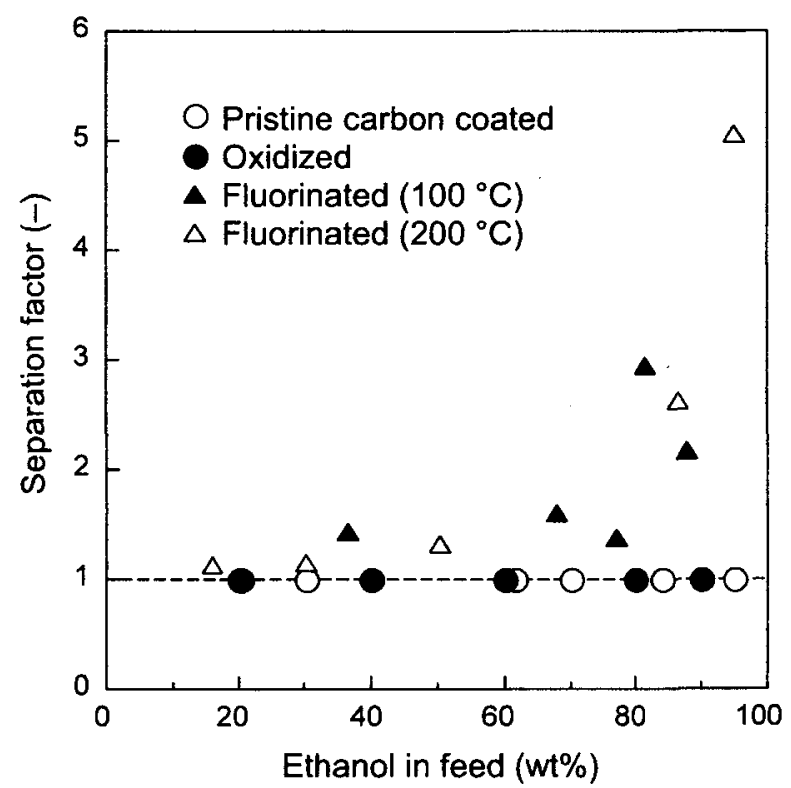

Fig.4 Plot of separation factor against ethanol concentration for the carbon-coated films in the pervaporation separation of water/ethanol mixture $\left(25^{\circ} \mathrm{C}\right)$.

処理は $50 \sim 200^{\circ} \mathrm{C}$ の温度範囲で 0.1MPa のフッ素ガスと炭素

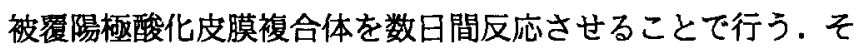
の後,フッ酸で鋳型を溶解除去することでフッ素化したナノ チューブを取り出ず).この場合は内面が外面より疎水性の高 いナノチューブとなる.

炭素被覆陽極酸化皮膜複合体は膜面に対して垂直にナノ メータオーダーの細孔が貫通しているので, 化学的安定性の 高い透過膜としても利用できる.水/エタノールの浸透気化実 験を酸化およびフッ素化処理した複合体を用いて行った例を 紹介する ${ }^{5}$.浸透気化実験では膜の片側を所定濃度のエタノー ル水溶液に接触させ，もう一方の側を減圧状態に保つ．そう すると，溶液が気化して膜を透過していく．その際の透過の 程度が水とエタノールで大きく違えば，この二つの成分のう ちどちらかが多い濃縮液を得ることができる．実際の実験で は透過側を $100 \mathrm{~Pa}$ 以下に保っておき，透過蒸気を液体窒素で

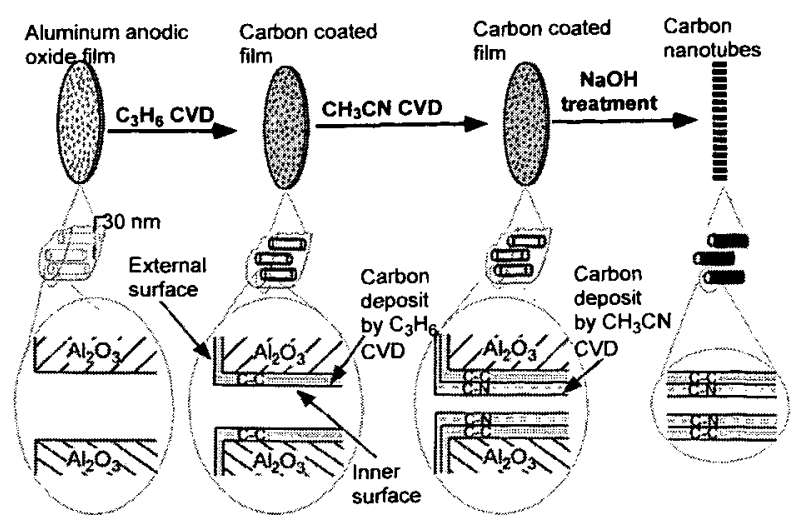

Fig.5 Schematic illustration of the synthesis of the carbon nanotubes with double coaxial structure of $\mathrm{N}$-doped and undoped multiwalls.

トラップした。つきにガスクロで供給液と透過液中のエ夕 ノール濃度を測定し, エタノールに対する水の分離係数 $\alpha(=$ $\left(\mathrm{Y}_{\mathrm{H}_{2} \mathrm{O}} / \mathrm{Y}_{\mathrm{E} \mathrm{FH}}\right) /\left(\mathrm{X}_{\mathrm{H}_{2} \mathrm{O}} / \mathrm{X}_{\mathrm{ErOH}))}\right.$ を求める.ここで $\mathrm{X}, \mathrm{Y}$ はそれそれ供 給液と透過液の濃度である. Fig.4に各複合膜の分離係数の供 給液濃度に対する変化を示す．末処理膜と硝酸処理膜はどの 濃度においても供給液濃度と透過液湮度は等しく $(\alpha=1)$, 水 とエタノールの分離は起こらなかった.フッ素処理した複合 体については，エタノール濃度が高い領域において， $\alpha$ が正 の值で透過液のエタノール濃度が供給液の濃度より低いこと がわかった。つまり，この領域ではフッ素処理膜は水選択透 過膜であった.フッ素処理により疎水化したチュープの内面 を水が選択的に透過した理由は明らかではないが，内面と相 互作用の少ない水の方がエタノールに比べて膜を通過しやす いのかもわからない，どちらにしても，内面フッ素化ナノ チューブは通常のナノチューブとはかなり性格が異なること だけは確かである.

2.3 二重構造カーボンナノチューブの合成

鋳型法を利用すれば外側と内側で組成の異なる二重構造の ナノチューブの合成も可能となる.その合成プロセスを Fig.5 に示す.この場合, 用いた原料はプロピレンとアセトニトリル $\left(\mathrm{CH}_{3} \mathrm{CN}\right)$ であり, 前者からは純カーボンが, 後者からは窒素 を含んだカーボンが堆積する. まず，細孔径 $30 \mathrm{~nm}$ の陽極酸 化皮膜に $800^{\circ} \mathrm{C}$, 2 時間の条件でプロピレンのCVDを行い,さ らに，800 C，5 時間でアセトニトリルの CVDを行うことで カーボン被覆陽極酸化皮膜複合体を調製する. その後，この 複合体をアルカリ処理することでアルミナを除去しナ， チューブを得るの. Fig.5から 1段目のCVDで純カーボン層が 堆積し，2段目のCVDで窒素を含んたカーボン層が純カーボ ン層の上に堆積することが理解できる.Fig.6にプロピレンだ けのCVDおよびプロピレンとアセトニトリルの2段階CVDに より調製したカーボンの透過型電子顕微鏡(TEM)写真を示す. どちらの場合も均一なサイスのナノチューブが生成し, プロ ピレンだけから調製したナノチューブの壁の厚さは $2.5 \mathrm{~nm}$ あり，2段階目のCVDにより壁の厚さは $4.4 \mathrm{~nm}$ まで厚くなっ 


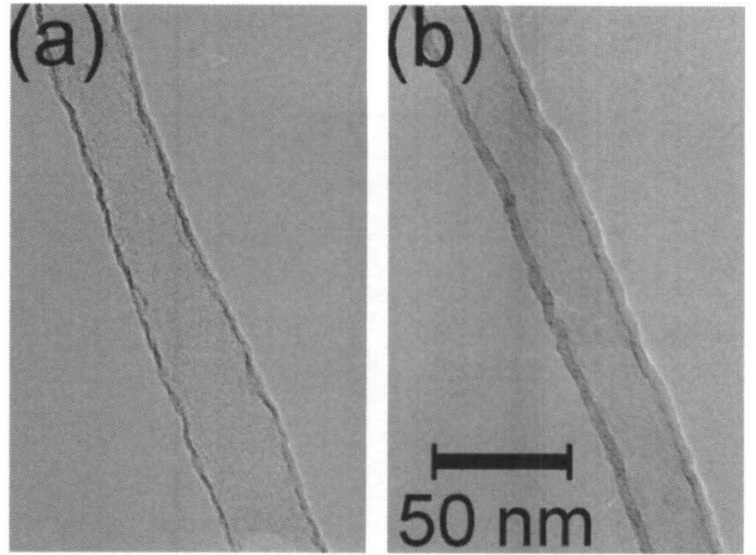

Fig.6 TEM images of the carbon nanotubes prepared by the propylene CVD (a) and the two-step CVD (b).

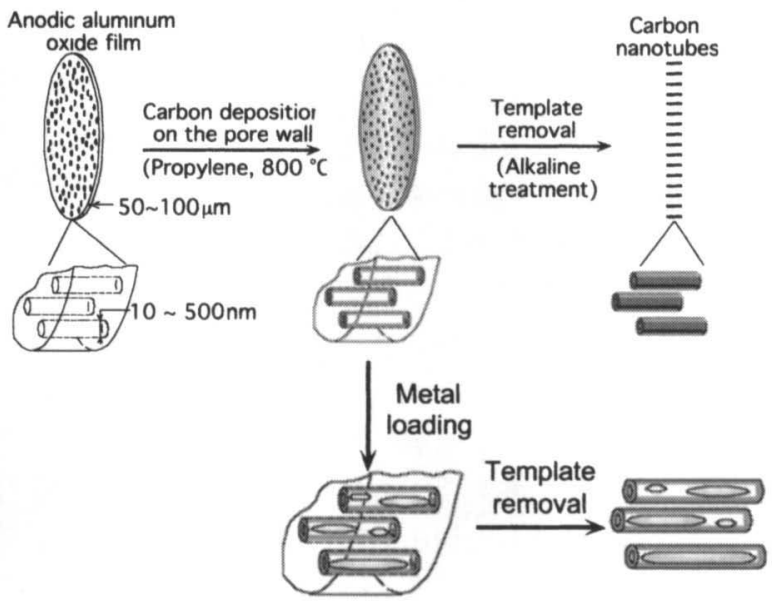

Fig.7 Introduction of foreign materials into the cavity of the carbon nanotubes.

た.もちろんチューブの外径は変化していない. 元素分析に よると,プロピレンCVDからのナノチューブは当然の事なが ら全く窒素を含んでいないが, 2段階CVDを施したものの窒 素含有量は3.2\%である.このように, 2段階CVD法で純力ー ボン層が外側で,窒素を含んだカーボン層が内側になった二重 構造のナノチューブを合成することができる.さらに, CVD の順序を逆にすれば，窒素を含んだカーボン層が外側で，純 カーボン層が内側のナノチューブもつくることができる.

このように鋳型法を利用すれば,ナノチューブ中の窒素原 子の分布あるいは位置を精密に制御することができる.さら にホウ素原子を含むカーボン層をCVD法で堆積させることも すでにできるようになれば, 一本のチューブでホウ素を含む p型のカーボン層と窒素を含むn型の層を同心円状に接合させ ることが可能となる.このような精密に構造が制御されたナ ノ p-n 接合の構築は, 従来までのナノチューブ製造方法であ るアーク放電法や炭化水素触媒分解法では困難であり, 鋳型 法により初めて実現させることができる.

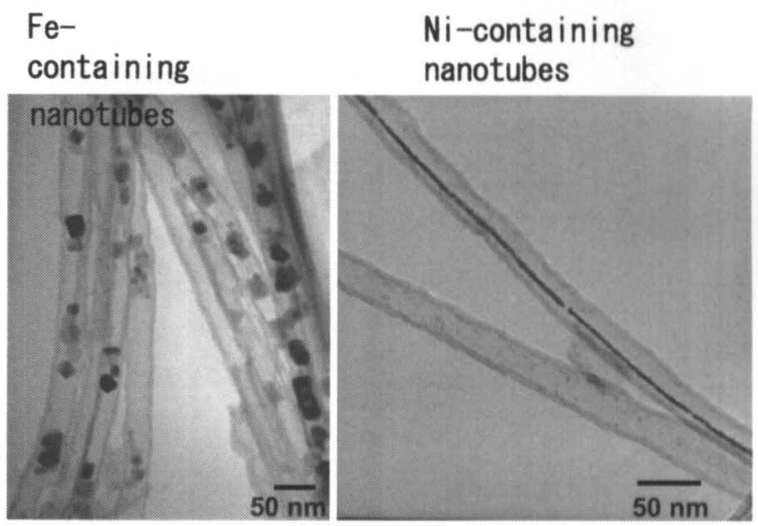

Fig.8 TEM images of the carbon nanotubes including $\mathrm{Fe}_{3} \mathrm{O}_{4}$ nanocrystals and $\mathrm{NiO}$ nano-ribbons.

2.4 カーボンナノチューブ内部への異種物質の挿入

カーボンナノチューブのナノサイスの空洞内に他の物質を 充填すれば, 今までにない新しい性質や構造を示す可能性か ある. そのため, カーボンナノチューブ内に金属などの異種 物質を導入し 1 次元ナノ複合体を合成しようとした試みは今 までも数多くあるが, ナノチューブの外部にも異種物質が付 着し, 内部だけに㨂入することは困難であった。しかし, 鋳 型法を利用すれば, 種々の異種物質をさまざまな形状でカー ボンナノチューブの内部だけに挿入させることが可能になる. つまり, Fig.7に示すように, 炭素/アルミナ複合膜の段階で 異種物質を担持した後, 鋳型を溶解除去すれば, 必然的にナ ノチューブの内部だけに異種物質は存在することになる.こ のような方法で $\mathrm{Fe}, \mathrm{Ni}$ を担持した例を紹介する.

$\mathrm{Fe}$ およびNiはそれぞれフェロセン $\left(\mathrm{Fe}\left(\mathrm{C}_{4} \mathrm{H}_{5}\right)_{2}\right)$ あるいはニッ ケロセン $\left(\mathrm{Ni}\left(\mathrm{C}_{4} \mathrm{H}_{5}\right)_{2}\right)$ を昇華させ, 複合膜を入れた反応管中に 水素流とともに導入し, $275 \sim 500^{\circ} \mathrm{C}$ で熱 CVD を行うことで 担持した. それそれの場合の TEM写真を Fig.8に示す. Feでは チューブ内部に数十 $\mathrm{nm}$ 程度のナノ粒子として存在しており, 各粒子の結晶性は非常に高く,そのいくつかは単結晶のように 見える. 電子線回折からこれらの粒子は酸化鉄 $\left(\mathrm{Fe}_{3} \mathrm{O}_{4}\right)$ と同定 できた》. $\mathrm{Ni}$ の場合は驚くべき事に直径約 $20 \mathrm{~nm}$ のナノチュー ブ内部に直径 $4 \mathrm{~nm}$, 長さ約 $500 \mathrm{~nm}$ の一本のワイヤが観察でき る.このワイヤ状のものは $\mathrm{NiO}$ の細長いリボンであり, ほほ 単結晶である. しかも, その(111)面はリボンの長軸に平行で あることが分かった 8.9 . その後の詳細な分析から, $\mathrm{Fe}$ と $\mathrm{Ni}$ の 場合にこのような結晶性の極めて高い酸化物がナノチューブ 内部に生成したのは, 鋳型であるアルミナ皮膜除去のために 行ったアルカリ処理が原因であることが明らかとなった9". フェロセンあるいはニッケロセンの熱CVDでチューブ内部に 生成した金属は空気に暴露することで酸化物となり,さらに オートクレイブ中のアルカリ処理で酸化物が溶解し, その後 再析出することで高い結晶性をもつに至ったと考えられる. つまり,ナノチューブ内部で金属酸化物の水熱反応が起こつ たと結論できる.この事実はカーボンを堆積させた陽極酸化 
皮膜の直線状ナノ細孔は水熱合成のような苛酷な条件の反応 場として利用することができることを示している.

そこで, $\mathrm{Ni}$ や Feの硝酸塩をカーボン被覆陽極酸化皮膜複合 体に含浸担持し，アルカリ処理することでアルミナ鋳型を除 去するとともに細孔内部の硝酸塩を水熱処理した. その後, カーボンナノチューブを空気で酸化除去することで，チュー ブ内部にあった水熱処理物を取り出した. $\mathrm{Ni}$ の硝酸塩から生 成物の SEM 写真を Fig.9 に示す ${ }^{10)}$. 均一なサイズのナノロッ ドが観察され，その径はナノチューブの内径に等しく $25 \mathrm{~nm}$ であった. また, 電子線回折からこれらのナノロッドは $\mathrm{NiO}$ の単結晶であることが分かった.このように本法は単結晶の 無機ナノロッドあるいはナノワイヤを合成するのに非常に有 効な方法である.

\section{3 次元鋳型を用いた多孔質カーボンの合成} 活性炭に代表される多孔質カーボン材料を特幑づけている のは, 構造中に存在している様々な大きさの細孔の存在とそ れに起因する大きな表面積である. とくに, 径 $2 \mathrm{~nm}$ 以下のミ ク口孔と径が $2 \sim 50 \mathrm{~nm}$ のメり孔の存在が吸着作用の源であ り, 多孔質カーボンの触媒材料としての性能や特性を支配し ているといっても過言ではない. したがって, 多孔質カーボ
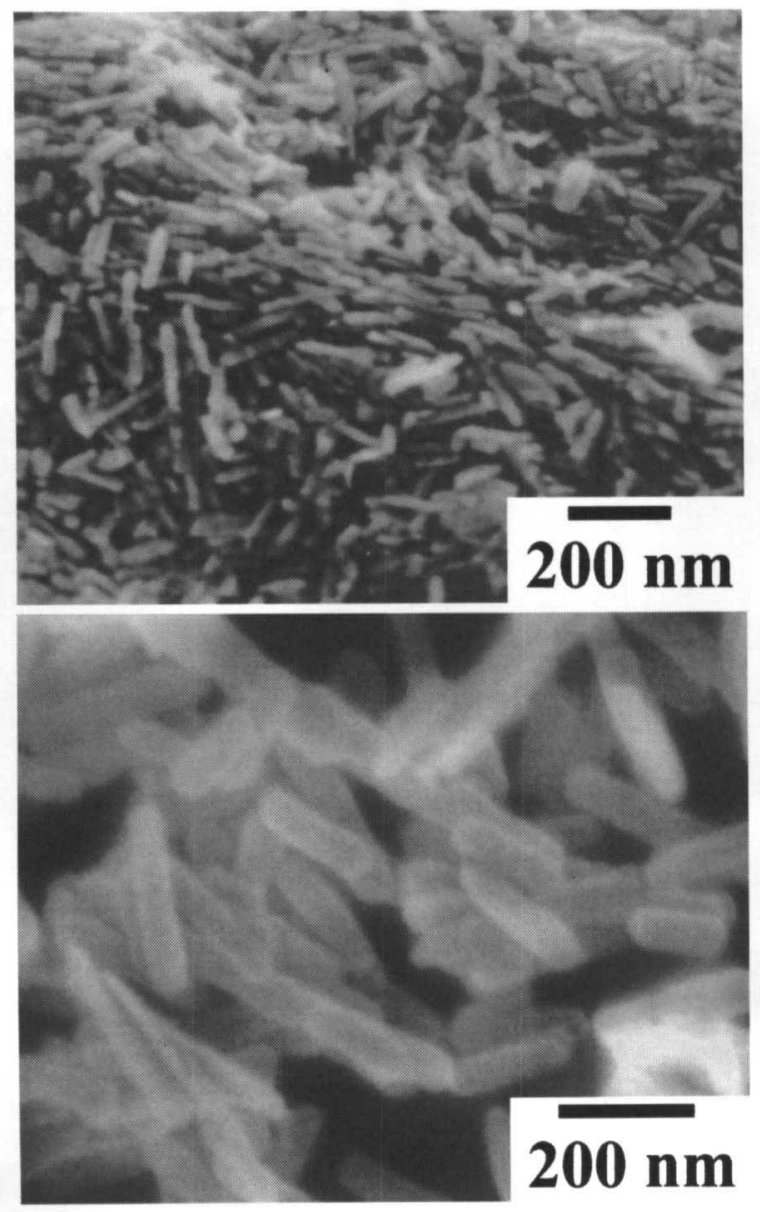

Fig.9 SEM images of single crystal $\mathrm{NiO}$ nanorods liberated from carbon nanotubes.
ンの高性能化を計り新しい機能を発現させるためにはミクロ 孔とメり孔の制御がまず第 1 に重要である. カーボンの細孔 は, ゼオライトのような規則的な結晶構造に由来する均一な 細孔とは違い, カーボン構造そのものが複雑であるため本質 的に不均一である. そのため, 細孔構造を自在に制御するこ とは簡単ではない，鋳型法では，無機鋳型の制御された構造 の規則性や秩序性を生成するカーボンの構造に活かすことが できる.したがって,この方法を利用すればカーボンの細孔 構造の精密制御も可能となる. 本節では鋳型法によるカーボ ンミクロ孔とメり孔の制御の試みについて紹介する.

3.1 ゼオライト鋳型によるミクロ孔の制御 ${ }^{11-15)}$

ゼオライトは分子レベルで制御された規則的な 3 次元細孔 をもっている. したがってゼオライトの細孔を炭素化の場と して利用すれば，ゼオライトの規則的な構造を反映した多孔 質カーボンをつくることができる，具体的にはつきのような 方法でゼオライトの細孔中にカーボンを充填する. 使用する ゼオライトはY $\mathrm{Y}$ 型ゼオライトで, フルフリルアルコールをゼ オライトに含漫した後, ゼオライト細孔内でフルフリルアル コールを熱重合する.つきに, このゼオライト複合体を高温 $\left(700^{\circ} \mathrm{C}\right.$ 程度 $)$ まで昇温し内部の重合物を炭素化させるととも に，同時にプロピレンを流通させることでゼオライト細孔内 にさらに熱分解カーボンを堆積させる. その後, 不活性気体 中で高温 ( $\left(900^{\circ} \mathrm{C}\right.$ 程度) 処理を行う.このようにして得られた カーボンドオライト複合体をフッ酸および塭酸で処理してゼ オライトを溶解除去することでカーボンを取り出す.

合成したカーボンと鋳型のY型ゼオライトのXRDパターン をFig.10に示す. Y 型ゼオライトにはその規則構造に由来す る多くの鋭い回折ピークが観察される.一方, カーボンには Y型ゼオライトの(111)面からのピークと同じ位置に鋭いピー クが現れ，このカーボンが距離約 $1.4 \mathrm{~nm}$ の長周期規則性を有 していることがわかる. しかし，この鋭いピーク以外には回 折ピークはなく, 通常のカーボンによく見られる $25^{\circ}$ 付近の ブロードな回折も現れない.このことから，このカーボンに は炭素六角網面の積層がほとんどないといえよう.

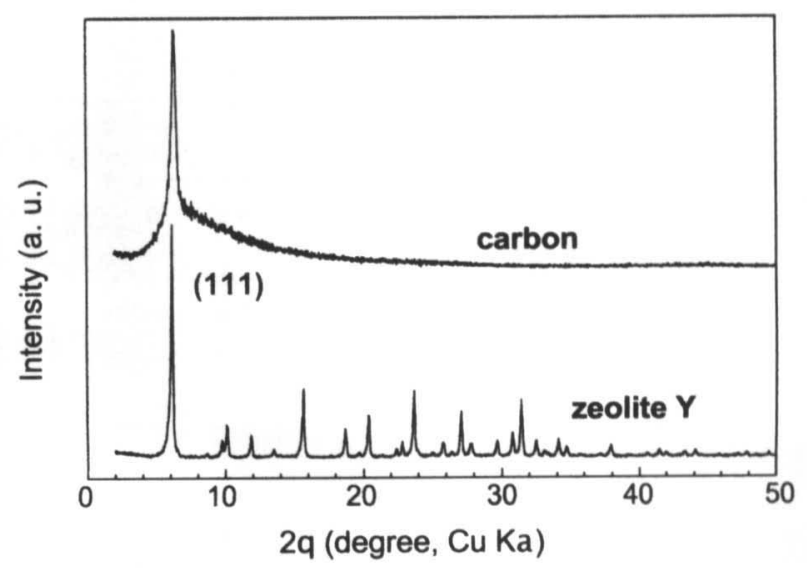

Fig.10 XRD patterns of zeolite $\mathrm{Y}$ and the carbon prepared using zeolite $\mathrm{Y}$ as a template. 
Fig.11にこのカーボンの TEM写真とこの視野の電子線回折 パターンを示す. TEM写真には約 $1.4 \mathrm{~nm}$ の間隔の規則的なア レイ構造が観察でき, 回折パターンにはこの配列に由来する 2 対の回折スポットが現れている.この規則的な配列構造は Y型ゼオライトの $\{110\}$ 面上のスーパーケージの並び方と同じ であり, 回折パターンは $\mathrm{Y}$ 型ゼオライトの $\{111\}$ 面の晶帯軸 <110>方向における回折と同一である. したがって，この方 法で合成されたカーボンにはY型ゼオライトの $<110>$ 方向に 平行な面の規則性, とくにスーパーケージの並びに直接対応 する $\{111\}$ 面の規則性が転写されていることがわかる.

Fig.12 にこのカーボンの $-196^{\circ} \mathrm{C}$ における $\mathrm{N}_{2}$ 吸着等温線を 示す. 等温線は典型的なI型であり, ミクロ多孔性であること がわかる. BET法により求めた比表面積は $3600 \mathrm{~m}^{2} / \mathrm{g}$ ときわめ て大きい值である. また, ミクロ孔容積は $1.5 \mathrm{cc} / \mathrm{g}$ と非常に大 きいが, ほとんどメり孔はない. 高比表面積の活性炭である KOH処理炭(AX21, Anderson Dev. Co.) と活性炭素瀻維(A-20, 大阪ガス俳)の等温線を Fig.12に併せて示す.これらの活性炭 の等温線も型であるが, ゼオライト鋳型からのカーボンの方 が低相対圧域での等温線の曲がり方が急である.このことは, ゼオライト鋳型からのカーボンの細孔構造が $\mathrm{AX} 21$ やA-20に 比べて均一で, ミクロ孔の細孔径分布が狭いことを示してい

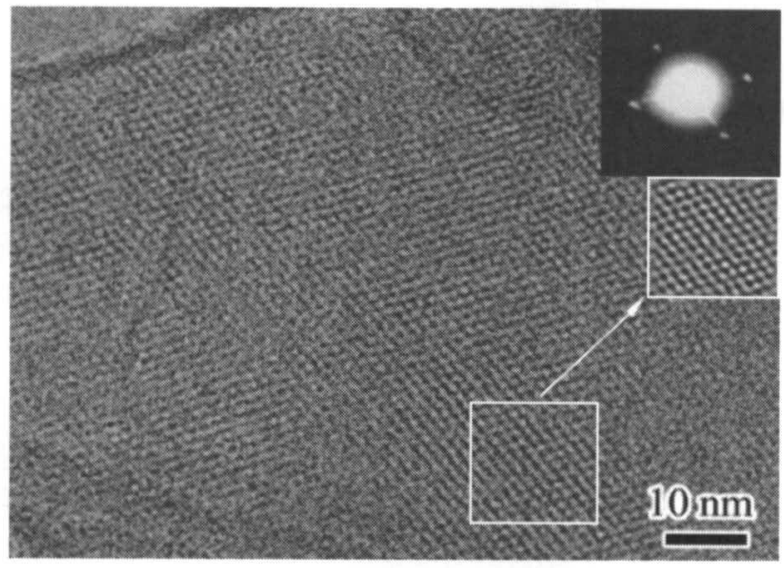

Fig.11 TEM image and electron diffraction pattern of the carbon obtained from zeolite $\mathbf{Y}$ as a template.

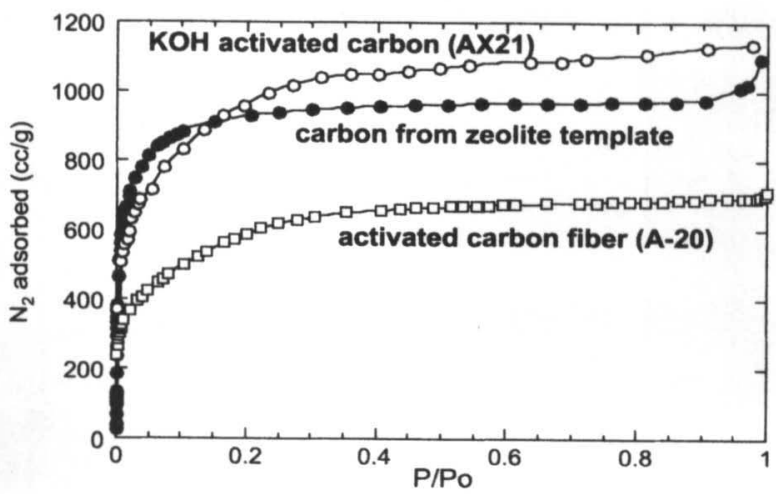

Fig.12 Nitrogen adsorption isotherms $\left(-196^{\circ} \mathrm{C}\right)$ of the template carbon and two other types of high surface area carbons.
る.このような均一な細孔構造を保っているのは, このカー ボンがゼオライト構造を反映した規則的な構造をしているた めであろう.

この方法で合成した規則的な 3 次元ナノアレイ構造を有す る多孔質カーボンは大きな表面積をもつがメり孔はほとんど なく,均一なミク口細孔構造している.このような構造は触媒 材料として魅力的であるばかりでなく, メタン吸蔵のための 吸着剂としても最適である. また, 大容量の電気二重層キャ パシターの電極材としても期待できる. また，その特異なナ ノ構造のため強磁性が発現することが確かめられている ${ }^{19}$. 3.2 メソポーラスシリカ鋳型によるメソ孔の制御

上で述べたように，規則的な 3 次元ミク口孔を有する $\mathrm{Y}$ 型 ゼオライトを鋳型として利用することで，規則的なミクロ孔 をもつ大表面積多孔質カーボンを合成できる，一方，ゼオラ イトより細孔径が大きいメりポーラスシリカを鋳型とすれば, メソ孔をもつ多孔質カーボンを合成することができる. MCM-48 と MCM-41 は規則的細孔をもつメりポーラスシリカ の代表例であり,どちらの場合も細孔径は2〜 $5 \mathrm{~nm} ゙$, MCM48 は規則的に交差した 3 次元状の細孔構造, MCM-41 は直線 状細孔を有している.これらのシリカの細孔に次のような方 法で炭素を充填する. シリカをショ糖と硫酸の水溶液に含浸 し, 細孔内のショ糖を $900^{\circ} \mathrm{C} て ゙$ 炭素化した後, アルカリ処理 でシリカを溶解除去しカーボンを取り出す市. あるいは, メ ソポーラスシリカを $\mathrm{AlCl}_{3}$ で処理することで酸触媒能をもつ $\mathrm{Al}$ サイトを導入してから, フェノールとホルムアルデヒドを 隇圧下で細孔内に充填する. その後, 細孔内で重合, 炭素化 を行い, フッ酸処理により細孔内のカーボンを取り出す ${ }^{18)}$.

どちらの場合でも, MCM-41 鋳型とした場合にはXRDで 鋭いピークを示さない無定形のカーボンとなったが, MCM48の場合はカーボンの規則的な構造に由来するXRDピークが 低角側に観察された. Fig.13にその結果を示す.取り出され

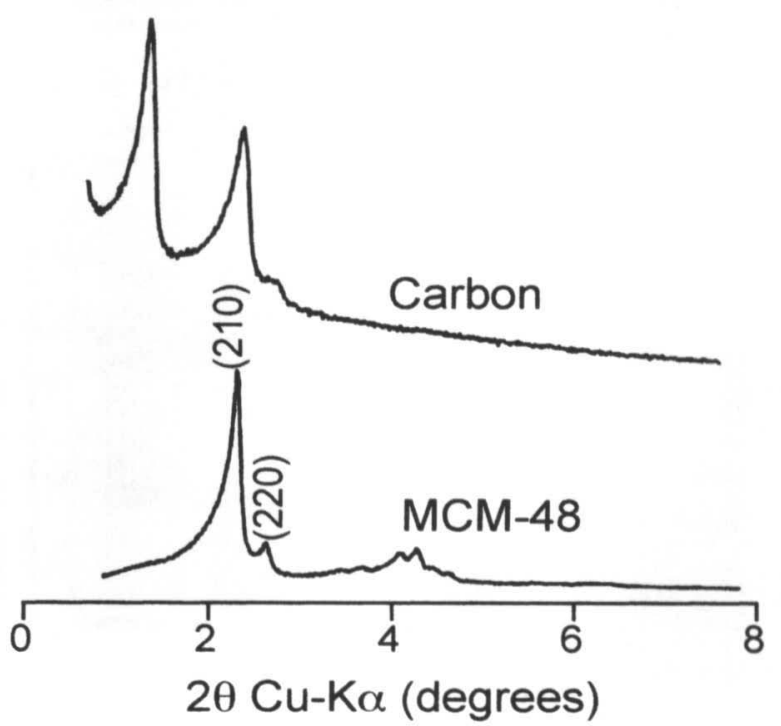

Fig.13 XRD patterns of MCM-48 and the carbon prepared using MCM-48 as a template. 
たカーボンにはMCM-48の (210) 面に対応すると思われる ピークとともにMCM-48には存在しないピークが $1.4^{\circ}$ に現れ ている.つまり,このカーボンは長周期の規則構造を有する が，それは鋳型の構造を完全に反映したものではないことを 示している.これはMCM-48の溶解過程て何らかの構造変化 が生じたためであると考えられる.Fig.14にこのカーボンのー $186^{\circ} \mathrm{C} の \mathrm{Ar}$ 吸着等温線とそれから求めた細孔径分布を示す. 相対圧が 0.3 付近で等温線にステッブが観察され，均一なメり 孔があることがわかる.Ar吸着により求めたカーボンの表面 積は $1380 \mathrm{~m}^{2} / \mathrm{g}$ であり，細孔径分布から規則構造に由来する単 分散な $3 \mathrm{~nm}$ のメソ孔と $0.5 \sim 0.8 \mathrm{~nm}$ のミクロ孔が存在してい ることがわかった.

メりポーラスシリカとしてMCM-48以外にも,SBA-1, SBA15, HMS などを鋳型として利用でき，同様な方法で均一なメ ソ孔をもつ多孔質カーボンを合成できる ${ }^{199}$.これらのメソ ポーラスシリカは界面活性剤の規則的なミセル構造を鋳型に して合成されており，界面活性剤の鎖長を変化させれば，そ の結晶格子のサイズや細孔径を制御できる。しかし，生成し てくる多孔質カーボンの細孔径を制御するには, シリカの細 孔径でなく細孔を形成している壁の厚さを変化させる必要が ある.MCM-48ではこのような壁の厚さの制御はすずかしい が, 界面活性刻としてへキサデシルトリメチルアンモニウム イオンと非イオン系であるポリエチレンオキシドを使い，こ れらの割合を変化させることで壁の厚さの異なるメソポーラ スシリカを合成することができるこのシリカを鋳型とする ことで, 生成してくるカーボンのメソ孔を $2 \sim 3 \mathrm{~nm}$ の狭い範 囲ではあるが精密に制御できる ${ }^{20)}$.

このような方法で合成されたメソポーラスカーボンは触媒 材料として利用できるほか, 電気二重層キャパシターの電極 材として利用すれば，充放電がきわめて早いキャパシターを つくることができる21).さらに，鋳型であるメりポーラスシ リカの細孔構造を知るためにも有効な情報を与えてくれる.

\section{4 ま と め}

錆型法を利用することで，構造がナノレベルで制御された カーボンナノチューブや多孔質カーボンを合成することがで きる.ナノチューブの場合では, その内面だけの選択的な化 学修飾や二重構造のナノチューフの合成など, 通常の方法で は困難なことも鋳型法を利用すれば容易に行うことができる． また,カーボンナノチューブの内部だけに貴金属や遷移金属 などを容易に挿入でき, 条件によりナノ粒子,ナノロッド,ナ ノリボンなどさまざまな形状のものをナノチューブの中だけ につくることができる，さらに，鋳型を除去する前のカーボ ン被覆陽極酸化皮膜複合体の直線状ナノ細孔は水熱合成の上 うな苛酷な条件の反応場として利用できることが分かった. さらに，ゼオライトやメソポーラスシリカを鋳型として利用 すれば，規則性の細孔構造をもつナノポーラスカーボンを合 成でき，今まで困難であったカーボンミクロ孔径の精密制御 も可能になった.このように鋳型法はカーボン材料の構造を

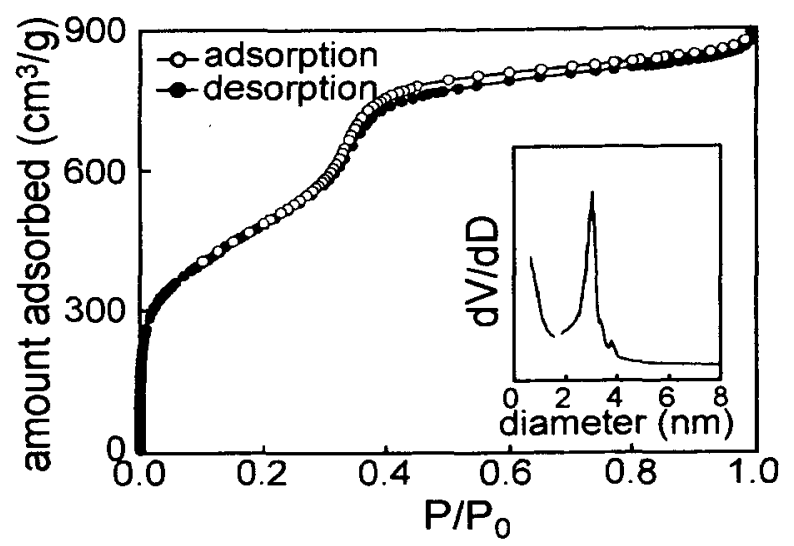

Fig.14 Argon adsorption-desorption isotherm $\left(-186^{\circ} \mathrm{C}\right)$ of the carbon from MCM-48 and its pore distribution curve determined from the isotherm.

精密に制御できるだけでなく，今までにないユニークなナノ 構造を棈築することができる極めて有効で便利な合成法であ るといえる。

\section{文献}

1) T.Kyotani, L.Tsai and A.Tomita: "Formation of Ultra-Fine Carbon Tubes by Using an Anodic Aluminum Oxide Film as a Template", Chem. Mater., 7(1995)1427-1428.

2) T.Kyotani, L.Tsai and A.Tomita: "Preparation of Ultrafine Carbon Tubes in Nano-Channels of an Anodic Aluminum Oxide Film", Chem. Mater., 8(1996)2109-2113.

3) T.Kyotani, S.Nakazaki, W.-H.Xu and A.Tomita: "Chemical Modification of the Inner Walls of Carbon Nanotubes by $\mathrm{HNO}_{3}$ Oxidation", Carbon, 39(2001)782-785.

4) Y.Hattori, Y.Watanabe, S.Kawasaki, F.Okino, B.K.Pradhan, T.Kyotani, A.Tomita and H.Touhara: "Carbon-alloying of the Rear Surfaces of Nanotubes by Direct Fluorination", Carbon, 37(1999)1033-1038.

5) T.Kyotani, W.-H.Xu, Y.Yokoyama, J.Inahara, H.Touhara and A.Tomita: "Chemical Modification of Carbon-Coated Anodic Alumina Films and Their Application to Membrane Filter", J. Membrane Sci., 196(2002)231-239.

6) W.-H.Xu, T.Kyotani, B.K.Pradhan, T.Nakajima and A.Tomita: "Synthesis of Aligned Carbon Nanotubes with Double Coaxial Structure of Nitrogen-Doped and Undoped Multiwalls", Advanced Materials, 15(2003)1087-1090.

7) B.K.Pradhan, T.Toba, T.Kyotani and A.Tomita: "Inclusion of Crystalline Iron Oxide Nanoparticles in Uniform Carbon Nanotubes Prepared by a Template Carbonization Method", Chem. Mater., 10(1998)2510-2515.

8) B.K.Pradhan, T.Kyotani and A.Tomita: "Nickel Nanowires of $4 \mathrm{~nm}$ Diameter in the Cavity of Carbon Nanotubes", Chem. Commun., (1999)1317-1318. 
9) K.Matsui, B.K.Pradhan, T.Kyotani and A.Tomita: "Formation of Nickel Oxide Nanoribbons in the Cavity of Carbon Nanotubes", J. Phys. Chem. B, 105(2001)5682-5688.

10) K.Matsui, T.Kyotani and A.Tomita: "Hydrothermal Synthesis of Single-Crystal $\mathrm{Ni}(\mathrm{OH})_{2}$ Nanorods in a Carbon-Coated Anodic Alumina Film", Advanced Materials, 14(2002)1216-1219.

11) T.Kyotani, T.Nagai, S.Inoue and A.Tomita: "Formation of New Type of Porous Carbon by Carbonization in Zeolite Nanochannels", Chem. Mater., 9(1997)609-615

12) Z.-M.Ma, T.Kyotani and A.Tomita: "Preparation of a High Surface Area Microporous Carbon Having the Structural Regularity of Y Zeolite", Chem. Commun., (2000)2365-2366.

13) Z.-M.Ma, T.Kyotani, Z.Liu, O.Terasaki and A.Tomita: "Very High Surface Area Microporous Carbon with a ThreeDimensional Nano-Array Structure: Synthesis and Its Molecular Structure", Chem. Mater., 13(2001)4413-4415.

14) T.Kyotani and A.Tomita: "Preparation of Novel Porous Carbons by Using Various Zeolites as Templates", J. Jpn. Petrol. Inst., 45(2002) 261-270.

15) Z.-X.Ma, T.Kyotani and A.Tomita: "Synthesis Methods for Preparing Microporous Carbons with a Structural Regularity of
Zeolite Y", Carbon, 40(2002) 2367-2374.

16) Y.Kopelevich, R.R.da Silva, J.H.S.Torres, A.Penicaud and T.Kyotani: "Local Ferromagnetism In Microporous Carbon with the Structural Regularity of Zeolite Y", Phys. Rev. B, 68(2003) 092408-1-4.

17) R.Ryoo, S.Hoon and S.Jun: "Synthesis of Highly Ordered Carbon Molecular Sieves via Template-Mediated Structural Transformation", J. Phys. Chem. B, 103(1999)7743-7746.

18) J.Lee, S.Yoon, T.Hyeon, S.M.Oh and K.B.Kim: "Synthesis of a new mesoporous carbon and its application to electrochemical double-layer capacitors", Chem. Comm., 13(1999)2177-2178.

19) R.Ryoo, S.H.Joo, M.Kruk and M.Jaroniec: "Ordered Mesoporous Carbons", Adv. Mater., 13(2001)677-681.

20) J.Lee, S.Hoon and R.Ryoo: "Synthesis of Mesoporous Silicas of Controlled Pore Wall Thickness and Their Replication to Ordered Nanoporous Carbons with Various Pore Diameters", J. Am. Chem. Soc., 124(2002)1156-1157.

21) K.Jurewicz, C.Vix-Guterl, E.Frackowiak, S.Saadallah, M.Reda, J.Parmentier, J.Patarin and F.Beguin: "Capacitance properties of ordered porous carbon materials prepared by a templating procedure", J. Phys. Chem. Solids, 65(2004)287-293. 